Nigerian Journal of Physiological Sciences 23 (1-2): 31-35 @Physiological Society of Nigeria, 2008

Available online/abstracted at http://www.bioline.org.br/np; www.ajol.info/journals.nips; www.cas.org

\title{
ACUTE TOXICITY STUDIES OF POTASSIUM PERMANGANATE IN SWISS ALBINO MICE
}

\author{
S.A. SAGANUWAN, V. M. AHUR AND C.A. YOHANNA ${ }^{1}$
}

Department of Veterinary Physiology, Pharmacology and Biochemistry, University of Agriculture, Makurdi Benue State, Nigeria . . Department of Veterinary Public Health and Preventive Medicine, University of Agriculture, Makurdi, Benue State, Nigeria. E- mail: pharn_saga2006@yahoo.com Tel: +234 8027444269, +2348026745993

\begin{abstract}
Summary: Acute toxicity study of potassium permanganate was carried out in Swiss albino mice. Potassium permanganate was administered at dose rate of $0.0,500,1000,1500,2000,2500,3000$ and 3500mg/kg body weight to groups $1,2,3,4,5,6,7$ and 8 , ten per group for $\mathrm{LD}_{50}$ determination. The dead animals were posted for gross lesions. A predetermined dose of $160 \mathrm{mg} / \mathrm{kg}$ of the chemical was administered to experimental group of 12 mice, whereas control group of 12 mice received $16 \mathrm{ml} / \mathrm{kg}$ body weight of distilled water for a period of 7 days. Grower's marsh and water were provided ad libitum. The animals were weighed daily before administration of potassium permanganate. On the eighth day $1 \mathrm{ml}$ of blood sample was collected from both control and experimental mice for haematology and plasma biochemistry into ethylene diamine tetraacetic acid bottles. The median lethal dose $\left(\mathrm{LD}_{50}\right)$ was estimated at $1449.7 \mathrm{mg} / \mathrm{kg}$ body weight. There was no significant difference between the mean weight of control and experimental group. Haematological and biochemical parameters of both control and experimental groups did not increase significantly though there was a significant $(\mathrm{P}<0.05)$ decrease in chloride ion level in plasma. Toxicity signs observed are rapid and shallow respiration, rough hair coat, dullness, diarrhoea, bloat, gastroenteritis, congestion of liver, paleness of lungs and hypochloraemia.

Keywords: Acute, toxicity, potassium permanganate, albino, mice
\end{abstract}

\section{Introduction}

Potassium permanganate is a salt of potassium used for disinfecting and cleaning wounds and as a general skin antiseptic. It irritates mucous membrane and is poisonous if taken into the body (Martin, 2002). It consists of dark, odourless, purple crystals with a metallic luster which are soluble in water giving pink to deep purple solutions depending on concentrations (Brander and Bywater, 1992a). Solutions of 1:1000 are used as wound and mouth lotions for antiseptic and deodorant purposes whereas $5 \%$ solutions are astringent (Pugh, 1992). The solution becomes inactive when turn to brown (Pugh, 1992). It has staining property which can be removed by oxalic and sulphuric acid (Brander and Bywater, 1992b). Ratios of $1: 4000$ to $1: 10,000$ solutions (Condy's lotion) are used as douche, irrigating cavities and urethra. Higher concentration caused burns and blistering. It is a water disinfectant (wells, ponds) and used as gastric lavage in alkaloidal poisoning but promotes rusting (Tipathi, 2003). It is an effective algicide $(0.01 \%)$ and virucide $(1 \%)$ but concentrations $>1: 10,000$ tends to irritate tissues (Khan, 2005). Hence it may contaminate water and can be toxic without prodromal signs. The main lesions are haemorrhage and necrosis of crop in birds (Jordan and Partison, 1999). Since potassium permanganate is still used clinically, there is need to assess the toxicity profile of the compound. Hence the study was aimed to investigating the acute toxicities of potassium permanganate in Swiss albino mice.

\section{Materials and methods}

One hundred and four (104) Swiss albino mice weighing between 11.0 and $27.1 \mathrm{~g}$ were purchased from National Veterinary Research Institute (NVRI) Vom, Plateau State Nigeria. They were acclimatized for 2 weeks and housed in cages. The mice were fed Grower's Marsh® (Grand Cereal and Oil Company (GCOL) Jos, Nigeria). Fresh clean water was provided ad libitum. Eighty (80) out of 104 mice weighing between 11.0 and $23.6 \mathrm{~g}$ were divided into 8 groups 1, 2, 3, 4, 5, 6, 7 and 8 of ten mice per group. A concentration of $12.5 \%$ Duke's brand potassium permanganate manufactured in Nigeria was prepared. Group 1 was administered $3500 \mathrm{mls} / \mathrm{kg}$ body weight of distilled water and served as control, whereas groups 2, 3, 4, 5, 6, 7 and 8 were administered orally $500,1000,1500,2000,2500,3000$ and $3500 \mathrm{mg} / \mathrm{kg}$ body weight of potassium permanganate for median lethal dose $\left(\mathrm{LD}_{50}\right)$ determination. The animals were observed for a period of 48 hours for acute toxicity signs. Lethal dose $\left(\mathrm{LD}_{50}\right)$ was calculated using the graphical method of Miller and Tainter (1937). A predetermined dose of $16.0 \mathrm{mg} / \mathrm{kg}$ body weight was 
administered to another 12 mice of group B whilst 12 mice of group A (control) was administered $16 \mathrm{ml} / \mathrm{kg}$ of body weight for a period of 7 days. The weight of control and experimental animals were taken every day before the administration of distilled water and potassium permanganate. A day after the last dosing of mice with potassium permanganate, blood sample $(1 \mathrm{ml})$ was collected from each mouse anaesthetized with ether into ethylene diamine tetraactate bottles for plasma haematology and biochemistry.

Full blood cells count was done using the method of Cheesbrough (2005). Albumin was determined using Biuret method (Tietz, 1995). Protein was determined using Bromocresol green method (Doumas, 1973). Conjugated bilirubin and total bilirubin were determined using the method of Jendrassik and Grof (1938). Alanine aminotransferase (ALT) and Aspartate aminotransferase (AST) were determined using the method of Reitman and Frankel (1957). Sodium $\left(\mathrm{Na}^{+}\right)$and potassium $\left(\mathrm{K}^{+}\right)$ions were determined using the method of Healay (1995). Bicarbonate and chloride ions were determined using the method of Chaney and Marbach (1962). The data on weight gain/loss, haemotological and biochemical parameters were analyzed using student ' $t$ ' test unpaired at 5\% level of significance (Petrie and Waston, 2002).

\section{Results}

The results of $\mathrm{LD}_{50}$ determination showed 0(0\%), 2(20\%), 4(40\%), 9(90\%), 8(80\%), 10(100\%) and $9(90 \%)$ deaths and $0(0 \%), 8(80), 6(60 \%)$, $1(10 \%), 2(20 \%), 0(0 \%)$ and $1(10 \%)$ survivors in groups $1,2,3,4,5,6,7$ and 8 respectively within a period of 48 hours post-administration of potassium permanganate. Fifty (50) out of eighty (80) mice administered potassium permanganate died within 48 hours post-administration. The estimated $\mathrm{LD}_{50}$ obtained using the graphical method of probit analysis was $1499.7 \mathrm{mg} / \mathrm{kg}$ body weight.

Signs of toxicity observed are rapid and shallow respiration, abdominal distension, intestinal contractility characterized by spontaneous purging and diarrhoea, hurdling, bloat, rough hair coat and dullness. Grossly, there was gastroenteritis, congestion of liver and paleness of lungs.

The mean weight of the animals of the control group was $20.3 \pm 1.1^{\mathrm{a}}$ whereas the mean weight of the animals from the experimental group was $21.3 \pm$ $1.5^{\mathrm{b}}$. There was no significant difference $(\mathrm{P}>0.05)$ between the weight of the control and experimental animals (Table 2).

Haematological parameters such as packed cell volume, neutrophils, lymphocytes, monocytes, eosinophils and basophils investigated in the acute toxicity studies did not increase significantly (P>0.05) (Table 3). Although, packed cell volume of the experimental group was slightly decreased in comparison with that of the control group. But neutrophils and monocytes of the experimental animals slightly increased in comparison with those of the control group.

All the parameters of plasma biochemistry investigated in this study did not increase significantly $(\mathrm{P}>0.05)$ except chloride ion which increased significantly $(\mathrm{P}<0.05)$. Nevertheless, total protein, Aspartate amino transferase (AST), Alanine aminotransferase (ALT), creatinine and sodium ion of the treated groups increased slightly. Whereas conjugated bilirubin and alkaline phosphatase of the experimental animals decreased slightly (Table 4).

Table 1: Estimation of median lethal dose $\left(L D_{50}\right)$ of potassium permanganate

\begin{tabular}{lcccccccc}
\hline Group & $\begin{array}{l}\text { Conc. } \\
\text { mg/kg }\end{array}$ & $\begin{array}{l}\text { Log }_{10} \\
\text { conc. }\end{array}$ & Total no. & $\begin{array}{c}\text { No. } \\
\text { death }\end{array}$ & $\begin{array}{c}\text { No } \\
\text { Survived }\end{array}$ & \% dead & Corrected & probit \\
\hline 1 & 0.00 & - & 10 & 0 & 0 & - & - & - \\
2 & 500 & 2.699 & 10 & 2 & 8 & 20 & - & 4.16 \\
3 & 1000 & 3.000 & 10 & 4 & 6 & 40 & - & 4.75 \\
4 & 1500 & 3.176 & 10 & 9 & 1 & 90 & - & 6.28 \\
5 & 2000 & 3.301 & 10 & 8 & 2 & 80 & - & 5.84 \\
6 & 2500 & 3.398 & 10 & 8 & 2 & 80 & - & 5.84 \\
7 & 3000 & 3.477 & 10 & 10 & 0 & 100 & - & - \\
8 & 3500 & 3.544 & 10 & 9 & 1 & 90 & - & 6.28 \\
\hline
\end{tabular}


Table 2: Effect of potassium permanganate on body weight of Swiss albino mice

\begin{tabular}{lcc}
\hline Day & $\begin{array}{c}\text { Control }(g) \\
(n-12)\end{array}$ & $\begin{array}{c}\text { Experimental }(g) \\
(n-12)\end{array}$ \\
\hline 1 & 21.1 & 19.6 \\
2 & 19.3 & 23.1 \\
3 & 20.8 & 21.4 \\
4 & 20.0 & 22.4 \\
5 & 19.8 & 21.0 \\
6 & 22.2 & 22.3 \\
7 & 19.2 & 19.2 \\
mean & $20.3 \pm 1.1^{\mathrm{a}}$ & $21.3 \pm 1.5^{\mathrm{b}}$ \\
\hline Key: smaller letters on the same row $=$ statistically not \\
significant.
\end{tabular}

Table 3: Effect of potassium permanganate on haematology of Swiss albino mice.

\begin{tabular}{lcc}
\hline \multicolumn{1}{c}{ Indices } & $\begin{array}{c}\text { Control }(n- \\
12)\end{array}$ & $\begin{array}{c}\text { Experimental } \\
(n-12)\end{array}$ \\
\hline Haematocrit \% & $41.00 \pm 2.08^{\mathrm{a}}$ & $39.29 \pm 2.43^{\mathrm{a}}$ \\
Neutrophils \% & $57.71 \pm 5.06^{\mathrm{a}}$ & $55.86 \pm 4.30^{\mathrm{a}}$ \\
Lymphocytes \% & $34.86 \pm 4.41^{\mathrm{a}}$ & $34.29 \pm 4.50^{\mathrm{a}}$ \\
Monocytes \% & $4.43 \pm 2.88^{\mathrm{a}}$ & $6.0 \pm 2.94^{\mathrm{a}}$ \\
Eosinophils \% & $3.00 \pm 1.52^{\mathrm{a}}$ & $3.86 \pm 1.57^{\mathrm{a}}$ \\
Basophils \% & $0.00 \pm 0.00^{\mathrm{a}}$ & $0.00 \pm 0.00^{\mathrm{a}}$ \\
\hline Key:
\end{tabular}

Key: smaller letters on the same row $=$ statistically not significant.

\section{Discussion}

The estimation of median lethal dose $\left(\mathrm{LD}_{50}\right)$ of potassium permanganate at dose rate of $1499.7 \mathrm{mg} / \mathrm{kg}$ body weight of mice is suggestive of toxicity of potassium permanganate. Other toxicity signs observed are rough hair coat, rapid and shallow respiration, abdominal distension, intestinal contractility accompanied by diarrhoea, dullness and bloat. Grossly, gastroenteritis, congestion of liver and paleness of lungs were also observed. Our findings agree with the report of Dreisbach and Robertson (1987) indicating that the $\mathrm{LD}_{50}$ is the amount of chemical that will kill approximately $50 \%$ of the group of animals. Our finding is supported also by the report of Humburger (1983) that median lethal dose $\left(\mathrm{LD}_{50}\right)$ is the ability of a compound to cause death and to do so in half of the animals when a certain dose is administered. However, the dangerous dose for humans may be $1-10 \%$ more or less of the determined dose (Dreisbach and Robertson, 1987). Our estimation of $\mathrm{LD}_{50}$ of potassium permanganate agrees with the findings of Brimblecombe and Dayan (1993) that acute toxicity tests are now used to establish an approximate lethal dose of a compound in different species using different routes of administration. The estimated value of $1499.7 \mathrm{mg} / \mathrm{kg}$ body weight of potassium permanganate as the $\mathrm{LD}_{50}$ in our study rated the compound slightly toxic using Hodge and Sterner scale but moderately toxic using Gosselin, Smith and Hodge scale (Gosselin et al., 1984; Garg, 2005). Shallow respiration observed in most test animals may be due to oxidizing effect of potassium permanganate. But gastroenteritis, abdominal distension and diarrhoea observed may be due to irritant action of the chemical. This was in line with the report of Martin (2002) indicating that potassium permanganate irritates mucous membrane and is poisonous if taken into the body. In an earlier study done by Tripathi (2003) he reported that higher concentrations of potassium permanganate cause burns, blistering and promote rusting. Khan (2005) in his study reported that concentration $>1: 10,000$ times irritate tissue. Although a total of 50 out of 80 experimental mice died in the period of $\mathrm{LD}_{50}$ estimation. However, the $\mathrm{LD}_{50}$ was represented by $50 \%$ probit value which was extrapolated to a corresponding $\log { }_{10}$ concentration. The value of $\log _{10}$ concentration was changed to antilog giving us $1499.7 \mathrm{mg} / \mathrm{kg}$ body weight. Since the $\mathrm{LD}_{50}$ does not lie within the range between 1500 and $3500 \mathrm{mg} / \mathrm{kg}$ body weight, many mice died of toxicity due to large doses used giving a loss of more than $50 \%$ of the test animals (Table 1). Lack of death of test mice in control group showed that there was no factor that caused death in the test animals other than potassium permanganate. Hence, potassium permanganate should be used with caution as mouth gargle, antidote for poisoning, antiseptic and disinfectant. Adequate care should be exercised to avoid ingesting a dose that may be too toxic to the body. Lack of significant difference $(\mathrm{P}>0.05)$ between the weight of control and experimental mice is suggestive of inability of potassium permanganate to cause weight gain or loss in Swiss albino mice. Moreso, there was no significant difference $(\mathrm{P}>0.05)$ in haematological parameters measured between the control and experimental group of mice. Although, packed cell volume $\left(39.29 \pm 2.43^{\mathrm{b}}\right)$ was slightly decreased in the experimental group as compared to the control group $\left(41.00 \pm 2.08^{\mathrm{a}}\right)$.

Insignificant difference $(\mathrm{P}>0.05)$ between plasma biochemistry of control and experimental groups of mice may be an indication of the inability of potassium permanganate to change biochemical parameters investigated. The significant hypochloraemia may be due to diarrhoea.

In our study, chloride ion was decreased (86.7 \pm $\left.34.27^{\mathrm{b}}\right)$ more than the sodium ion $\left(137.8 \pm 1.68^{\mathrm{a}}\right)$, hence it may be a selective chloride loss. Hypochloraemic animals are alkalotic and persistent hypochloraemia is an indication for sodium, 
potassium and acid-base determination (Willard, 1989). When faeces contain excess chloride, there is bicarbonate generation with potassium loss leading to hypokalaemic alkalosis (Eastham, 1983). That was why bicarbonate ion was slightly increased (25.29 \pm $1.25^{\mathrm{a}}$ ) in our study. It is usually easier to determine the cause of alterations in these parameters than to determine the cause of hypchloraemia alone (Willard, et al., 1989).

\section{Conclusion}

Potassium permanganate caused death in $50 \%$ of test mice at dose rate of $1499.7 \mathrm{mg} / \mathrm{kg}$ body weight. The chemical is slightly to moderately toxic. The toxicity signs observed are rough hair coat, rapid and shallow respiration, abdominal distension followed by diarrhoea, bloat, dullness, gastroenteritis, congestion of liver and paleness of lungs. Potassium permanganate caused hypchloraemia perhaps due to diarrhoea. But it has no effect on weight, haematological and other biochemical parameters at dose rate of $16 \mathrm{mg} / \mathrm{kg}$ body weight. Therefore, the chemical should be used with caution as mouth gargle, antidote for poisoning, antiseptic and disinfectant. Therefore, potassium permanganate should be kept away from children.

Table 4: Effect of potassium permanganate on plasma biochemistry of Swiss albino mice

\begin{tabular}{lcc}
\hline \multicolumn{1}{c}{ Indices } & Control $(n-12)$ & Experimental $(n-12)$ \\
\hline Total protein $(\mathrm{gm} / \mathrm{L})$ & $68.31 \pm 2.37^{\mathrm{a}}$ & $69.43 \pm 1.93^{\mathrm{a}}$ \\
Albumin $(\mathrm{gm} / \mathrm{L})$ & $36.64 \pm 1.86^{\mathrm{a}}$ & $36.63 \pm 1.62^{\mathrm{a}}$ \\
$\begin{array}{l}\text { Unconjugated bilirubin } \\
(\mu \mathrm{mol} / \mathrm{L})\end{array}$ & $14.93 \pm 1.86^{\mathrm{a}}$ & $14.31 \pm 0.32^{\mathrm{a}}$ \\
$\begin{array}{l}\text { Conjugated bilirubin } \\
(\mu \mathrm{mol} / \mathrm{L})\end{array}$ & $3.12 \pm 0.54^{\mathrm{a}}$ & $2.64 \pm 0.16^{\mathrm{a}}$ \\
Alkaline phosphatase & $128.29 \pm 11.35^{\mathrm{a}}$ & $127.0 \pm 7.23^{\mathrm{a}}$ \\
$(\mathrm{IU} / \mathrm{L})$ & & \\
Aspartate & $14.00 \pm 2.76^{\mathrm{a}}$ & $16.71 \pm 2.14^{\mathrm{a}}$ \\
aminotransferase $(\mathrm{IU} / \mathrm{L})$ & & \\
Aspartate alanine & $6.43 \pm 2.44^{\mathrm{a}}$ & $7.57 \pm 1.81^{\mathrm{a}}$ \\
transferase $(\mathrm{IU} / \mathrm{L})$ & & \\
Urea $(\mathrm{mmol} / \mathrm{L})$ & $3.01 \pm 0.51^{\mathrm{a}}$ & $3.41 \pm 0.71^{\mathrm{a}}$ \\
Creatinine $(\mathrm{mmol} / \mathrm{L})$ & $83.85 \pm 10.14^{\mathrm{a}}$ & $86.57 \pm 2.30^{\mathrm{a}}$ \\
Sodium ion $(\mu \mathrm{mol} / \mathrm{L})$ & $136.43 \pm 2.15^{\mathrm{a}}$ & $137.8 \pm 1.68^{\mathrm{a}}$ \\
Potassium ion $(\mathrm{mmol} / \mathrm{L})$ & $3.41 \pm 0.24^{\mathrm{a}}$ & $3.53 \pm 0.43^{\mathrm{a}}$ \\
Chloride ion $(\mathrm{mmol} / \mathrm{L})$ & $101.14 \pm 3.08^{\mathrm{a}}$ & $86.71 \pm 34.27^{\mathrm{b}}$ \\
Bicarbonate ion $(\mathrm{mmol} / \mathrm{L})$ & $25.00 \pm 1.91^{\mathrm{a}}$ & $25.29 \pm 1.25^{\mathrm{a}}$ \\
\hline \multicolumn{1}{c}{$K e y: \operatorname{sinilurletts} 0 n$} & & \\
\hline
\end{tabular}

Key: similar letters on the same row $=$ statistically not significant.

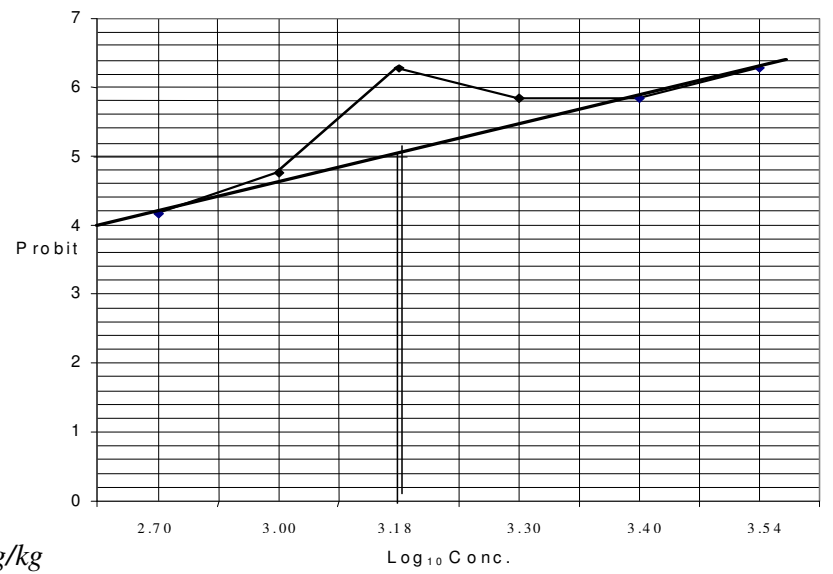

Figure 1: Determination of $L D_{50}$ of potassium permanganate using probit graph 


\section{Reference}

Brander, G. C. and Bywater, R. J. (1992a). Disinfectant and antiseptics In: Applied Veterinary Pharmacology and Therapeutics (Brander, G. C., Pugh, D. M., Bywater, R. J. and Lenkins, W. L. eds.), Sixth ed., WB Saunders, UK Pp 51-588.

Brander, G. C. and Bywater, R. J. (1992b). Potassium permanganate. Applied Veterinary Pharmacology and Therapeutics. (Brander, G. C., Pugh, D. M., Bywater, R. J. and Lenkins, W. L. eds.), Sixth ed., WB Saunders, UK. P 581.

Brimblecombe, R. W. and Dayan, A. D. (1993). Preclinical toxicity testing In: Pharmaceutical Medicine (Burley, D. M., Clarke, C. and Lusanga, L. eds). London, Great Britain, UK. Pp 13-32.

Chaney, A. L. and Marbach, A. L. (1962). $\mathrm{HCO}_{3}{ }^{-}$ $\mathrm{Cl}^{-}$titration method. Clin. Chem. 8:130-133.

Cheesbroungh, M. (2005). Measurement of plasma or serum creatinine. District Laboratory Practice in Topical Countries Part 1, Cambridge University Press, London, UK p. 333.

Doumas, B.T., Watson, W. A. and Biggs, H. B. (1991). Albumin-bromocresol green method. $J$. Clin. Pathol.13:156-159.

Dreisbach, R. H. and Robertson, W. O. (1987). Alcohol and Glycols. A handbook of poisoning: Prevention, Diagnosis and Treatment. Appleton and Large, London pp 176.

Eastham, R. D. (1983). Reduced plasma chloride. A guide to water electrolyte and acid-base metabolism, Wright PSG, Bristol, Great Britain pp 42-43.

Garg, S. K. (2000). General toxicology In: Veterinary Toxicology (Garg, S. K. 2000). CBS Publishers and Distributors, Darya Ganj, New Delhi, India. p 9.

Gosselin, R. E., Smith, R. P. and Hodge, H. C. (1984). Clinical Toxicology of Commercial Products. Williams and Wilkins Baltimore, London, United Kingdom.

Healy (1995). Electrolytes: Their role and management. In: District Laboratory Practice in Tropical Countries Part 1 (Cheesebrough, M. ed).. Cambridge University Press, London, UK. pp 54.
Hamburger, F. (1983). In-vitro testing in the study of toxicity and safety evaluation. A Guideline to Toxicology, Pp 196-207.

Jendrassik. L. and Grof. (1938). In-vitro determination of total and direct bilirubin in serum. J. Biochem. 299:81-88.

Jordan F. T. W. and Pattison, M. (1991). Some poisons and toxicants; potassium permanganate. Poultry Diseases, $4^{\text {th }}$ ed., WB Saunders, London, UK. pp 332-342.

Khan, C.M. (2005). Potassium permanganate. The Veterinary Merck Manual, Merck and Co. Inc. U.S.A., pp 2155.

Martin, E. A. (2003). Potassium permanganate. $6^{\text {th }}$ ed., Oxford University Press, Oxford Britain. pp 552-553.

Miller, L. C. and Tainter, M. I. (1937). Estimation of $\mathrm{LD}_{50}$ or $\mathrm{ED}_{50}$ values and their errors using LogProbit graph paper. Proc. Soc. Expt. Biol. Med. 57: 261-264

Petrie, A. and Watson, P. (2002). Statistics of Veterinary and Animals Sciences, Blackwell Science Limited, UK 78-88.

Reitman, S. and Frankel, S. (1957). Quantitative invitro determination of glutamic-pyruvic transaminase in serum. Ann. J. Clin. Pathol. 28:56-66.

Tietzs, N. W. (1998). Total protein determination. Clinical Guide to Laboratory Tests, $3^{\text {rd }}$ ed., W. B. Saunders, Philadelphia pp 518-519.

Tripathi, K. D. (2003). Drugs acting on skin and mucous membrane. Essentials of Medical Pharmacology, $5^{\text {th }}$ ed., New Delhi, India pp 793.

Willard, M. D. (1989). Causes of hypochloraemia In: Small Animal Clinical Diagnosis by Laboratory Methods (Willard, M. D., Tvedten, H. and Turnwald, G. H. eds.), W. B. Saunders, London UK pp 113.

Willard, M. D., Tvedten, H. and Turnwald, G. H. (1989). Electrolyte and acid-base abnormalities. Small Animal Clinical Diagnosis by Laboratory Methods, WB Saunders, London, UK. pp. 103120. 